\title{
A Steam Heat Generation System for Pre-Treatment of Oil Bearing Seeds for Efficient Oil Extraction
}

\author{
Agidi Gbabo ${ }^{1^{*}}$, Andrew N. Efomah ${ }^{2}$, and Gana Ibrahim Mohammed ${ }^{3 *}$ \\ ${ }^{1}$ Department of Agricultural and Bioresources Engineering, Federal University of Technology, Minna, Niger State, \\ Nigeria. \\ ${ }^{2}$ Department of Agricultural and Biosystems Engineering, University of Ilorin, Ilorin, Kwara State, Nigeria. \\ ${ }^{3}$ Department of Agricultural and Bioenvironmental Engineering, Federal Polytechnic Bida, Niger State, Nigeria. \\ Email: ganaibro74@yahoo.com
}

\begin{abstract}
A steam toasting machine for pre-treatment of oil bearing seeds was designed and fabricated by Desfabeng Company Nigeria Limited Bida, Nigeria. The major component of the machine includes; hopper, heating unit, conveyor, toasting unit, electric motor of $0.25 \mathrm{~kW}$ and a gear motor of $0.25 \mathrm{~kW}$. Results of testing of the system revealed maximum oil yield of $42 \%, 46 \%, 48 \%$ and $40 \%$ for neem oil $(8 \% \mathrm{mc})$, ground nut oil $(6 \% \mathrm{mc})$, sesame oil $(6 \%)$ and shea nut $(10 \% \mathrm{mc})$ respectively. Also the result of physicochemical analysis of the oil sample showed that the values ranged from 0.3 to 2.87 for free fatty acid, 0.38 to $2.93 \mathrm{mg} / \mathrm{g}$ for peroxide value, and $39.12 \mathrm{mg} / \mathrm{g}$ to $106.16 \mathrm{mg} / \mathrm{g}$ for iodine value. The capacity of the system was 4 tons per day. The new system will help in eliminating the shortcoming associated with direct toasting of oilseeds with open fire.
\end{abstract}

Keywords: Oilseed, heat, steam, oil extraction, design, fabrication

\section{Introduction}

Oil bearing seeds and nuts are agricultural plant products that contain oil as one of their by-products. These by-products include vegetable oil, sesame oil, shea butter among others. They have numerous socio-economic and health benefits. According to [1], vegetable oil is an extract of ground nut which is primarily used as cooking and salad oil. It has high quality and can withstand higher temperature without burning or breaking down. Also it has neutral flavour, odour and does not absorb odour from other foods. According to [2] and [3] shea butter is oil obtained from shea nut. It has numerous application and uses among which is in manufacturing of soap, candles, cosmetics, pharmaceutical products and substitutes. Sesame plant is grown mostly for the oil extracted from the seed. This oil is edible and used for industrial and pharmaceutical purposes [4]. Also it is used in the production of performs, skin conditioning agents, moisturizers, hair cream, bath oil, insecticides, paints and drugs [5]. Sesame seed has been reported to contain about $35 \%$ to $60 \%$ of oil [4]. Neem oil is an extract of neem seeds. This oil is used in cosmetic production and in pharmaceutical industries as a supplementing ingredient in medicine production. It is also used as insect repellent, feeding inhibitors, egg laying detorents, growth retardant and as sterilizer. In addition it has systematic action on plant for controlling fungal diseases.

In extraction of oil from oil bearing agricultural products, it undergoes certain preliminary processing. These preliminary processing aids in efficient oil extraction and makes the process easier. Some of these preliminary processes are removal of hulls, shells, pre-treatment conditioning such as size reduction, optimum moisture content adjustment, pre-heat treatment and pressure application. These activities depend on the nature of the oil-bearing material and the methods and devices to be adopted in the oil extraction. Oil-seeds are subjected to heat treatment in order to lower the viscosity of the oil to be extracted, coagulate the protein in the meal, and also adjust the moisture level of the meal to the optimum level of extraction [6].

Most oil seeds and nuts are heat-treated by direct roasting to liquefy the oil in the plant cells and facilitate its release during extraction. This has the disadvantage of affecting the physical and chemical properties of the oil produced due to the presence of burnt seeds leading to black oil formation. Due to 
these disadvantages researches are been carried out to ensure even roasting of the seeds without burning. This has led to efforts been placed on the possibility of using steam as a source of heat energy to steam the oil seeds prior to expelling. Also large scale oil production involves the use of bigger equipments which are sophisticated, costly and difficult to maintain by the local processors. On the other hand the small scale edible oil producers make use of direct roasters which affects the physico-chemical properties of the oil due to the formation of black oils arising from burnt seeds. This necessitated the fabrication of a suitable oilseed pre-heat treatment system using steam for oil extraction. This paper therefore explains the design, fabrication and testing of an oilseed pre-heat treatment system which would be capable of heating up the oil bearing cells of oilseeds thereby releasing the semi-solid nature of oil in seeds into its oily state with low viscosity. This machine would be found very useful in the vegetable oil production industry thereby increasing indigenous oil production and reducing oil importation.

\section{$2 \quad$ Materials and Methods}

\subsection{Material for Construction}

The materials of construction were locally sourced; the gear electric motor, pulleys and the belts were purchased. The machine various unit were made of mild steel (16 gauge). The Construction of the machine was carried out by marking out the plate and sizing using scriber and share cutters. Shafts were turned on lathe machine while seams and various components were welded with gauge 10 electrodes; Assembly of parts was done with fasteners (bolt \& nuts) [2].

\subsection{Material for Construction}

A $100 \mathrm{~kg}$ each of four different types of oil bearing seeds of shea nut (V. paradoxa), ground nut (samnut 10), neem seed (A. indica) and sesame (white) were used for this study. The seeds were obtained from Niger State Agricultural Development Project Zonal Office Bida, Nigeria. The materials were cleaned to remove dirt, broken seed and other foreign materials. The samples were prepared at four different moisture contents of $6,8,10$ and $12 \%$ (d.b). In order to obtained moisture content below the initial moisture content of the samples, the samples were kept in an oven at a constant temperature of $43 \mathrm{oC}$ until the desired moisture content was obtained [7]; [8]. The desired higher moisture content were achieved by adding calculated quantity of distilled water using the following Eq. (1) as reported by [7].

where, $\mathrm{Q}=$ mass of added water $(\mathrm{kg})$

$$
Q=W_{i}\left(M_{f}-M_{i}\right) / 100-M_{f}
$$

$\mathrm{Wi}=$ initial mass of the sample $(\mathrm{kg})$

$\mathrm{Mf}=$ final moisture content of the samples (\% d.b)

$\mathrm{Mi}=$ initial moisture content of the samples $(\% \mathrm{~d} . \mathrm{b})$

\subsection{Machine Components}

The oil seed pre-heat treatment system is made up of the following components as described below:

i. The Hopper: this is conical in shape and helps to direct clean dried oilseeds into the toasting takes chamber. It is conical in shape and made from gauge "16" mild steel plate

ii. The Discharge Chute: this is an inclined (450C) rectangular trough at the bottom of the toaster made from mild steel metal sheet. It serves as a passage for already toasted seeds to flow freely into the expeller as shown Figures 1 and 4.

iii. Heating Unit: this is a plywood insulated rectangular housing constructed in order to hold water for the purpose of boiling and steam generation as shown in Figures 1 and 4 . Incorporated to the heating unit is a $5 \mathrm{~kW}$ heating element for heating up the water for steam generation. Gate valves are used to control the flow of steam from the heating unit to the toasting unit.

iv. The Toasting Unit: as shown in Figures 1 and 4, this comprises of three concentric cylinders held together at the bottom by a flat circular metal sheet and at the top by short metal rods. This concentric cylinder has three chambers. The first chamber is the 
insulated chamber where an insulator is used to lag the cylinder so as to minimise heat loss from the steam chamber. The second chamber is the steam chamber where the steam passes through and circulates so as to heat up the body of the third cylinder which serves as the actual toaster. A stirrer is attached to the toasting unit for stirring of the seeds during steam application so as to ensure even heating up of the seeds.

v. The Conveyor: the conveyor is of the screw (auger) type. It serves the purpose of moving loaded seeds from the ground where one end of the conveyor fits into a seed container. The auger then moves these seeds through a rotary motion and empties it at the other end into the hopper of the toaster.

vi. The Frame Work and Power Transmission Unit: the frame is made of strong rectangular hollow pipes braced at the base in order to provide strength and support to the machine. The power transmission unit is a $1 \mathrm{hp}$ gear motor together with an electric motor to power the conveyor. This is shown in Figures 1 and 4 .

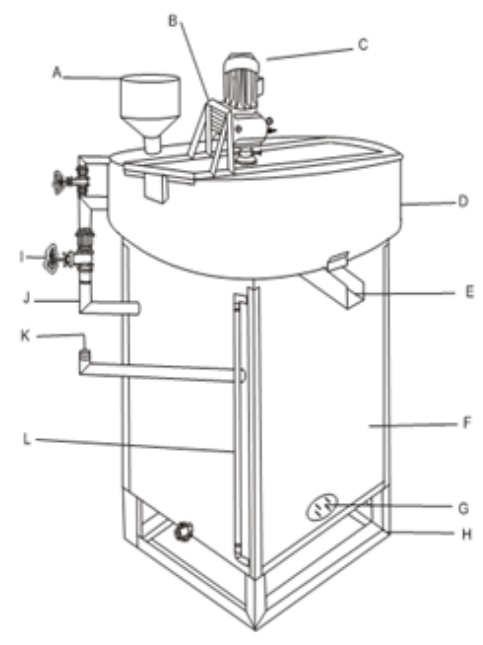

\begin{tabular}{|l|l|}
\hline KEYS & DESCRIPTION \\
\hline A & HOPPER \\
\hline B & GEAR MOTOR FRAME \\
\hline C & GEAR MOTOR \\
\hline D & TOASTNG UNIT \\
\hline E & DISCHARGE CHUTE \\
\hline F & HEATING UNI \\
\hline G & HEATING ELEMENT \\
\hline H & FRAME \\
\hline I & STEAM REGULATION VALVE \\
\hline J & STEAM DELIVERY PIPE \\
\hline K & WATER NLET PORT \\
\hline L & WATER LEVEL NDICATOR \\
\hline M & STIRRER \\
\hline
\end{tabular}

Figure 1. Isometric view of the nut heater

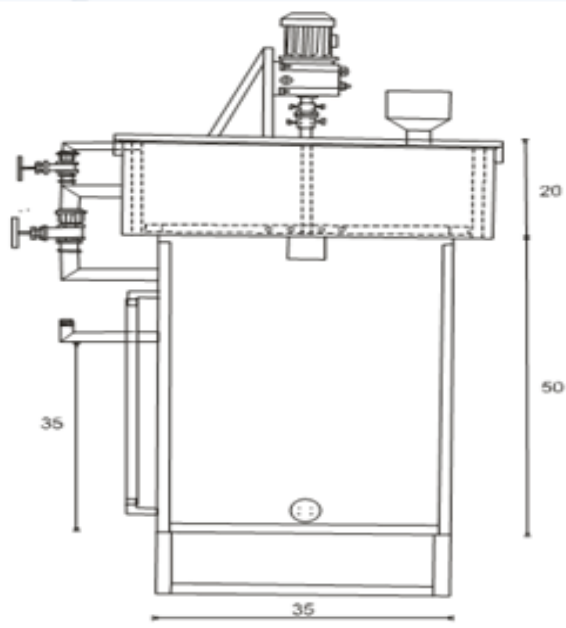

Figure 2. Orthographic side view. 


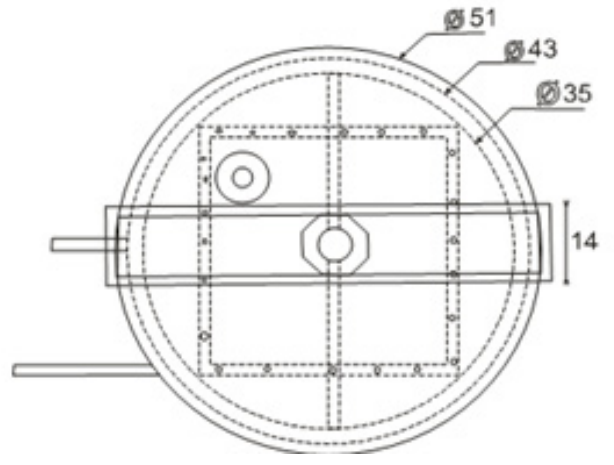

Figure 3. Orthographic plan view.

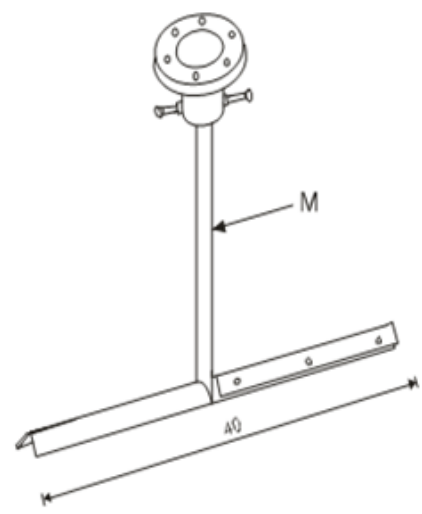

Figure 4. The stirrer.

\subsection{Design Calculation}

Essential design analysis and calculation were carried out in order to determine and select materials of appropriate strength and sizes.

\subsubsection{Power Required to Stir the Oilseeds}

The power required to stir the oil seed was determined by as reported [9] as

$$
\begin{gathered}
P_{s}=T_{s} W_{s} \\
W=2 \pi N / 60 \\
T_{s}=F r
\end{gathered}
$$

where, Ps $=$ Power required to stir the oilseeds $(\mathrm{kW})$

$\mathrm{Ts}=$ Torque of the stirrer $(\mathrm{Nm})$

$\mathrm{Ws}=$ Angular velocity of the stirrer $(\mathrm{rad} / \mathrm{sec})$

$\mathrm{N}=$ Speed of the stirrer

$\mathrm{F}=$ the stirring force required to stir the seeds

$\mathrm{r}=$ distance of point of application from the axis of rotation (force radius)

\subsubsection{Power Required to Drive the Stirrer Shaft}

This was determined as reported by [2] as;

$$
\begin{aligned}
& P_{w}=W_{w} \times r_{w} \\
& W_{w}=M_{w} \times g
\end{aligned}
$$


where, $P_{w}=$ ower required to drive the stirrer shaft $(\mathrm{kW})$

$W_{w}=$ The weight of the stirrer shaft $(\mathrm{N})$

$r_{w}=$ adius of the stirrer shaft $(\mathrm{m})$

$M_{w}=$ Mass of the stirrer shaft $(\mathrm{kg})$

$g=$ Acceleration due to gravity $(\mathrm{m} / \mathrm{s} 2)$

\subsubsection{Power Required to Drive the Pulley}

This was determined as reported by [2] as;

$$
\begin{aligned}
& P_{p}=W_{p} \times r_{p} \\
& W_{p}=M \times g
\end{aligned}
$$

where, $P_{p}=$ Power required to drive the pulley $(\mathrm{kW}), W_{p}=$ eight of the pulley $(\mathrm{N}), r_{p}=$ radius of the pulley $(\mathrm{m}), \mathrm{M}=$ mass of the pulley $(\mathrm{kg}), \mathrm{g}=$ Acceleration due to gravity $(\mathrm{m} / \mathrm{s} 2)$

2.4.4 Determination of the Speed of the Belt

The speed of the belt can be determined by using the expression reported by [9]

$$
V=\pi \times N \times D / 60
$$

where, $\mathrm{V}=$ Speed of belt $(\mathrm{rpm}), \mathrm{N}=$ Speed of the electric motor pulley (rpm), $\mathrm{D}=$ Diameter of the electric motor pulley $(\mathrm{m})$

\subsubsection{Design of Pulley and Belt}

This is done in order to know the equivalent ratio between the size of the electric motor pulley and that of the auger pulley. This was determined as reported by [9]

$$
N_{1} D_{1}=N_{2} D_{2}
$$

where, $N_{1}=$ Speed of the electric motor pulley $(\mathrm{rpm}), \mathrm{D}_{1}=$ Diameter of the electric motor pulley $(\mathrm{m})$, $\mathrm{N}_{2}=$ Speed of the conveyor pulley (rpm), $\mathrm{D}_{2}=$ Diameter of the conveyor pulley (m)

\subsubsection{Determination of the Maximum Shear Stress of the Stirrer Shaft}

The shaft was subjected to combined load of bending moment and torque. The maximum shear stress was determined as reported by [9] and is given as:

$$
\tau_{\max }=16 / \pi d^{3} \sqrt{M^{2}+T^{2}}
$$

where, $\tau_{\max }=$ Maximum shear stress $(\mathrm{N} / \mathrm{m}), \mathrm{T}=$ Torque $(\mathrm{Nm}), \mathrm{M}=$ Bending moment of shaft $(\mathrm{Nm})$, $\mathrm{D}=$ shaft diameter $(\mathrm{m})$

\subsubsection{Total Quantity of Heat (Steam) Required}

This is the total sum of the theoretical heat required to toast the seeds and the expected heat loss from the toaster. It is computed using the relationship below [10]

$$
\begin{gathered}
Q=M_{a}\left(h_{2}-h_{1}\right)+E H L \\
M_{a}=\frac{V_{f}}{V_{s}} \\
Q=\frac{V_{f}}{V_{s}}\left(h_{2}-h_{1}\right)+E H L \\
Q_{h}=\frac{Q}{H_{c}}
\end{gathered}
$$

where, $\mathrm{EHL}=$ the Expected Heat Loss, $\mathrm{Q}=$ the total heat requirement $(\mathrm{KJ}), h_{1}=$ the enthalpy of the ambient environment $(\mathrm{KJ} / \mathrm{Kg}), \quad h_{2}=$ the final enthalpy of the toaster environment after steaming $(\mathrm{KJ} / \mathrm{Kg}), M_{a}=$ the mass flow rate of steam $(\mathrm{Kg} / \mathrm{sec}), V_{f}=$ the volumetric flow rate of steam $\left(\mathrm{m}^{3} / \mathrm{sec}\right)$, $V_{s}=$ the specific volume of steam $(\mathrm{m} 3 / \mathrm{sec}), H_{c}=$ the rated heat capacity of each heating element, $Q_{h}=$ quantity of heat required $(\mathrm{KJ})$

\subsubsection{Time Required to Toast a Batch}

The time required to toast a batch of oilseed is computed using the equation shown below: 


$$
T=\frac{N_{B}}{T_{T}}
$$

where, $\mathrm{T}=$ the time required per Batch, $T_{T}=$ Total time required, $N_{B}=$ number of batches

\subsubsection{Belt Tensions}

The belts that transmit power from the electric motor to the auger of the conveyor are subjected to tension due to the frictional resistance between the belt and pulley. The tension of the belt on the tight and slack side is expected not to be lower or exceed a particular limit in order for power transmission from the electric motor to the conveyor to be effective. These tensions were determined using the mathematically established equations [11]

$$
\begin{gathered}
T_{1}=U \\
T_{2} / W=\left(\left(T_{1}-T_{2}\right) / 60\right) V
\end{gathered}
$$

where, $\mathrm{T}_{1}=$ tension on the tight side, $\mathrm{T}_{2}=$ tension on the slack side, $\mathrm{U}=$ coefficient of friction between belt and pulley, $\mathrm{V}=$ velocity of belt $(\mathrm{m} / \mathrm{sec})$

\subsubsection{Heat Loss through the Walls of the Toasting Unit}

Heat loss through the inner wall, second wall, insulator and outer wall of the toasting unit was expected hence, it was put into consideration in the design. Due to symmetry, any cylindrical surface concentric to the axis of the tube is an isothermal surface and the direction of heat flow is normal to the surface [12]. Considering the toasting unit as a cylinder made of different materials, Fourier's law of heat conduction was applied;

The surface area of the cylinder is:

$$
A_{r}=2 \pi r l
$$

When Fourier's equation is applied:

$$
q=-K A_{r} \frac{d T}{d r}
$$

Substituting equation 18 into 19 gives:

$$
q=-2 K \pi r l \frac{d T}{d r}
$$

After rearranging and applying limits from r1 to r2, the equation becomes

The heat loss

$$
q=2 K \pi l\left(T_{1}-T_{2}\right) / \ln \left(r_{2} / r_{1}\right)
$$

For a three concentric cylinder having an insulator

$$
q=2 \pi l\left(T_{1}-T_{5}\right) /\left(\ln \left(r_{2} / r_{1}\right) / K_{A}+\ln \left(r_{3} / r_{2}\right) / K_{B}+\ln \left(r_{4} / r_{3}\right) / K_{C}+\ln \left(r_{5} / r_{4}\right) / K_{D}\right)
$$

Thermal resistance, $\mathrm{RC}$, is given by

$$
R_{C}=\frac{\frac{\ln \left(r_{2} / r_{1}\right)}{K_{A}}+\frac{\ln \left(r_{3} / r_{2}\right)}{K_{B}}+\frac{\ln \left(r_{4} / r_{3}\right)}{K_{C}}+\frac{\ln \left(r_{5} / r_{4}\right)}{K_{D}}}{2 \pi l}
$$

where, $\mathrm{L}=$ Depth of the toaster $(\mathrm{m}), \mathrm{T}_{1}=$ Temperature inside the roaster $(0 \mathrm{C}), \mathrm{T}_{5}=$ Temperature of the surrounding $(0 \mathrm{C}), \mathrm{r}_{1}=$ Internal radius of the inner cylinder (toasting chamber) $(\mathrm{m}), \mathrm{r}_{2}=$ Internal radius of the second cylinder (steam chamber) $(\mathrm{m}), \mathrm{r}_{3}=$ External radius of the second cylinder (steam chamber) $(\mathrm{m}), \mathrm{r}_{4}=$ Internal radius of the outer cylinder (insulator chamber) $(\mathrm{m}), \mathrm{r}_{5}=$ External radius of the outer cylinder (insulator chamber) $(\mathrm{m}), \mathrm{K}_{\mathrm{A}}=$ Thermal conductivity of the inner cylinder $(\mathrm{W} / \mathrm{m} 0 \mathrm{c}), \mathrm{K}_{\mathrm{B}}=$ Thermal conductivity of the second cylinder $(\mathrm{W} / \mathrm{m} 0 \mathrm{c}), \mathrm{K}_{\mathrm{C}}=$ Thermal conductivity of the insulator (foam), $\mathrm{K}_{\mathrm{D}}=$ Thermal conductivity of the outer cylinder $(\mathrm{W} / \mathrm{m} 0 \mathrm{c}$ )

\subsubsection{Heat Loss through the Walls of the Heating Tank}

For a homogenous material of 1-D geometry between two end points at constant temperature, heat loss is given by:

$$
q=-K A(\Delta T / \Delta x)
$$


where, $\mathrm{A}=$ cross sectional surface area $(\mathrm{m} 2), \Delta T=\quad$ mperature difference between the ends $(0 \mathrm{C})$

$$
U=K / \Delta x
$$

where, $\mathrm{U}=$ Conductance $(\mathrm{W} / \mathrm{m} 2 \mathrm{~K})$

Therefore

$$
q=U A(-\Delta T)
$$

The reciprocal of conductance is resistance, $\mathrm{R}$, given by:

$$
R=1 / u=\Delta x / k=A(-\Delta T) / q
$$

Considering the heating tank as a heterogeneous material having two layers of metal sheets and a layer of an insulator (plywood);

$$
q=-K A \frac{\Delta T}{\Delta x}
$$

where, $\mathrm{q}=$ Heat loss $(\mathrm{kJ}), \mathrm{A}=$ cross sectional surface area $(\mathrm{m} 2), \Delta T=$ Temperature difference between the ends $(0 \mathrm{C}), \Delta x=$ Thickness of the individual material $(\mathrm{m}), \mathrm{K}_{1}=$ Thermal conductivity of the metal sheet $(\mathrm{W} / \mathrm{m} 0 \mathrm{C}), \mathrm{K}_{2}=$ Thermal conductivity of insulator $(\mathrm{W} / \mathrm{m} 0 \mathrm{C})$

\subsubsection{Determination of the Volume of the Heating Unit}

The heating unit is a cuboidal shaped tank having length, breadth and height. The formular for calculating the volume of a cuboid was therefore applied. The quantity of water to be poured into the heating unit would be half of the volume of the heating unit

$$
V=L \times B \times H
$$

where, $\mathrm{V}=$ Volume of heating tank $(\mathrm{m} 3), \mathrm{L}=$ Length of heating tank $(\mathrm{m}), \mathrm{B}=$ Breadth of heating tank $(\mathrm{m}), \mathrm{H}=$ Height of heating tank $(\mathrm{m})$

\subsubsection{Determination of the Volume of the Toasting Unit}

The toasting chamber is cylindrical in shape having three different diameters and a common height, as such; the formular for calculating the volume of a cylinder was applied. The volume of the toaster is a pointer to the maximum quantity of seed that it can accommodate per batch operation given by the formular:

$$
V=\pi r^{2} h
$$

where, $\mathrm{V}=$ Volume of toasting chamber $(\mathrm{m} 3), \pi=3.142=$ Radius of toaster $(\mathrm{m}), \mathrm{h}=$ Height of the toaster $(\mathrm{m})$

\subsection{Mode of Operation of the Machine}

The various parts of the machine were assembled, after which the electric motor was mounted to power the auger (conveyor) assembly. The machine was first run under no loaded this was done to ascertain proper working condition of the machine. The heating unit was filled with water to half of its volume. This is to provide sufficient space for steam expansion. The heating element was then switched on for boiling process to commence. The material sample was loaded at the base of the conveyor from where it was conveyed into the toasting unit. As soon as sufficient steam has been generated, the steam gate valve was opened and the steam moved to the steam chamber of the toasting unit. The stirring of the material was carried out in continuous manner at low speed. The material was checked at intervals until a complete toasting was achieved. The seed outlet chute was opened and the toasted seeds were released into an expeller for extraction processes. The oils were expressed using a Desfabeng Company Nigeria Limited Bida, Niger State, Nigeria developed oil seed expeller. The expeller capacity ranged from 20-30 $\mathrm{kg} / \mathrm{h}$ and was powered by a $10 \mathrm{~kW}, 3$ phase electric motor with in-built reduction gear. It was run at 75 rpm [13].

\subsection{Testing of the Machine}

Two experiments were carried out in order to evaluate the performance of the machine. In the first experiment samples of groundnut, sesame, crushed shea nut and neem seed were varied at four different moisture content levels of 6,810 and $12 \%$ (d.b) and the effects of moisture content on oil yield of the sample were determined. The samples were introduced into the toaster at different intervals and 
different batch operations in order to carry out the toasting process. Oil Expressed and cakes from the samples were collected separately. Cleaning of the expeller barrel was done after each expression. Each of the experiments was repeated for three times and the average values were taken. The expressed oil was collected and left to stand for 96 hours as recommended by [14] the volume measured. The weights of the cakes were determined by use of an electronic weighing balance. The recorded oil yield was compared with the initial oil content of the seed.

\subsubsection{Percentage of Oil Yield}

The percentage of oil yield was obtained using the following equation reported by [15], as:

$$
Y_{O}=W_{O} / W_{S}
$$

where $Y_{O}$ the percentage of oil yield (\%), $W_{O}=$ eight of oil extracted from a batch, $W_{S}$ total weight of seeds

In the second experiment some physicochemical properties of the extracted oils which include Free fatty acid content (FFA), Iodine value (PV), saponification value and acid value were determined.

\subsubsection{Free Fatty Acid Content}

This was determined by adding $25 \mathrm{~mL}$ of methanol to $1.5 \mathrm{~g}$ each of the oil sample contained in the flask; the mixture was boiled in a water bath and then allowed to cool. Two drops of phenolphthalein was added to the solution and $0.1 \mathrm{~N} \mathrm{NaOH}$ was used to titrate the mixture. It was computed as reported by [15] as

$$
F F A=V \times 0.0282 \times 100 / W_{S}
$$

where FFA Free fatty acid content $(\%), \mathrm{V}=$ volume of the sample $\left(\mathrm{cm}^{3}\right), \mathrm{Ws}=$ weight of sample $(\mathrm{g})$

\subsubsection{Iodine Value}

This was determined by weighing 1gram of fat sample into a stoppered bottle and $25 \mathrm{~mL}$ of Wij's solution was added to it. It was mixed properly and allowed to stand for $1 \mathrm{~h}$. A blank was prepared with chloroform. With $50 \mathrm{~mL}$ distilled water the stopper and neck of the flask were rinsed thoroughly. Ten milliliters of KI solution was added to it and then titrated with standard sodium thiosulphate (y) till it turned pale yellow. After that few drops of starch solution was added and titrated till blue colour disappears. The steps were repeated with a blank which did not contain any fat sample (x). The unsaturated fatty acid residues of the glycerides react with iodine, and the iodine value indicates the degree of unsaturation of the fatty acid residues of the glycerides (Bhandare and Naik 2015).

\subsubsection{Saponification Value}

This was determined by weighing $1 \mathrm{~g}$ of each of the oil sample in different conical flasks and $3 \mathrm{~mL}$ of fat solvent was added to each flask. Twenty-five milliliters of ethanol potash was added and refluxed for 30 min with frequent shaking. After cooling, two drops of phenolphthalein indicator was added to each flask and titrated with $0.5 \mathrm{M} \mathrm{HCl}(\mathrm{x})$ with vigorous shaking without delay to get the end point. The step was repeated for a blank which did not contain oil sample (y). It was computed as reported by [15]

$$
S V=28.05 \times \mathrm{Tv} / W_{S}
$$

where, $\mathrm{SV}=$ Saponification value, $\mathrm{Tv}=$ Titre value, $W_{S}=$ Weight of sample $(\mathrm{g})$

\subsubsection{Acid Value}

The acid value $(\mathrm{AC})$ of the reaction mixture was determined by the acid-base titration technique [16]

\section{$3 \quad$ Results and Discussion}

\subsection{Effects of Moisture Content on Oil Yield}

The result of effects of moisture content on oil yield of the samples is presented in Figure 5. Sesame seed produced the highest oil yield of $48 \%$ at $6 \%$ moisture content (d.b) while ground nut produce lower oil yield of $20 \%$ at $12 \%$ moisture content (d.b). The values of oil yield range from $35 \%$ to $42 \%$ for neem oil, $20 \%$ to $46 \%$ for ground nut oil. Others are $25 \%$ to $48 \%$ and $35 \%$ to $40 \%$ for sesame oil and shea butter respectively. It can be observed that sesame, groundnut and neem seed kernels with higher moisture content yielded less oil as compared to those with lower moisture content; this agrees with the findings by [13] who reported maximum oil recovery for neem expressed at $8.1 \%$ moisture content. The authors reported further that increasing the moisture content to $10 \%$ decreased the oil recovery. On the 
other hand for shea nut the maximum oil yield was obtained at $10 \%$ moisture content and increase in moisture to $12 \%$ yielded lesser oil. However, from the figure, it can be observed that moisture contents at each level recorded significantly different oil yield.

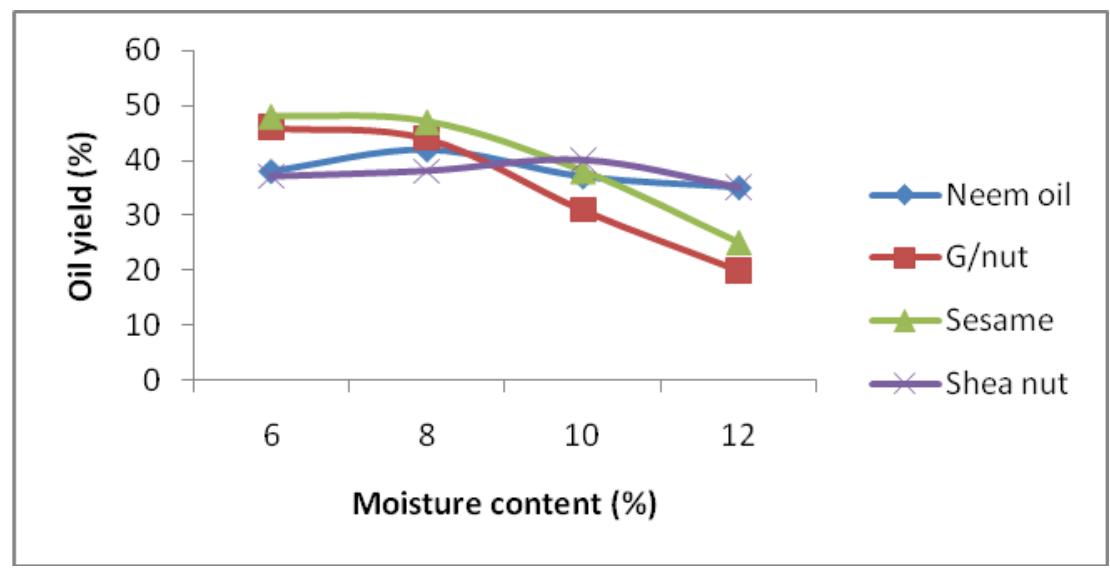

Figure 5. Effects of moisture content on oil yield

For sesame seed the maximum oil yield of $48 \%$ was observed at $6 \%$ while the minimum oil yield of $25 \%$ was recorded at the highest moisture content. The optimum moisture content falls between 6 and $8 \%$. Similar trend was observed with groundnut seed where the maximum oil yield of $46 \%$ was observed at $6 \%$ while the minimum oil yield of $20 \%$ was recorded at the highest moisture content. The optimum moisture content falls between 6 and $8 \%$. On the other hand for neem seed the maximum oil yield of $42 \%$ was observed at $8 \%$ while the minimum oil yield of $35 \%$ was recorded at the highest moisture content. For shea nut the maximum oil yield of $40 \%$ was observed at $10 \%$ while the minimum oil yield of $35 \%$ was recorded at the highest moisture content. Increasing moisture content of the seed beyond $6 \%$ for sesame and ground nut seeds led to lower oil yield. Also increasing moisture content beyond $8 \%$ and $10 \%$ for neem and shea nut seeds respectively, led to lower oil yield. This implies that higher moisture content means lower oil yield as far as this experiment and the oil bearing seeds under investigation is concerned. [17] reported that moisture content has highest influence on sesame oil yield; he added that to increase oil yield, moisture content has to be reduced. [18] used mathematical models to predict oil expression from sesame seed and soya bean respectively; the author also found that moisture content had the greatest influence on oil yield. [19] and [20] all reported that moisture content most suitable for screw press are commonly within $7-8 \%$.

\subsection{Nature of the Extracted Oil}

The yield of oil from the seeds without pre-heating was insignificant, as only pastes were observed coming out of the cake outlet of the expeller. This was in agreement with [21] who reported very low yield of oil when groundnut seeds were not heated prior to expelling. Also [22] suggested that incorporating a heating chamber along the expeller barrel of an oil expeller helps in improving its extraction efficiency. The entire oil samples extracted using the developed machine were fresh and clean (Table 1).

Table 1. Nature of the extracted oil

\begin{tabular}{l|l|l|l}
\hline $\begin{array}{l}\text { Type of Oil } \\
\text { Seeds }\end{array}$ & $\begin{array}{l}\text { Percentage of Oil yield before pre- } \\
\text { heat treatment (\%) }\end{array}$ & $\begin{array}{l}\text { Ave. Percentage of Oil yield after pre- } \\
\text { heat treatment (\%) }\end{array}$ & $\begin{array}{l}\text { Nature of oil } \\
\text { extracted }\end{array}$ \\
\hline Groundnut & Only pastes formed & 46 & Fresh and clean \\
\hline Sesame & Only pastes formed & 48 & Fresh and clean \\
\hline Shea nut & Only pastes formed & 40 & Fresh and clean \\
\hline Neem seed & Only pastes formed & 42 & Fresh and clean \\
\hline
\end{tabular}




\subsection{Result of Physicochemical Analysis of the Oil Sample}

The maximum oil yield of each of the oil sample was subjected to physicochemical analysis. The result of physicochemical analysis of the oil sample is presented in Table 2 . The average values range from 0.3 to 2.87 for free fatty acid, 0.38 to $2.93 \mathrm{mg} / \mathrm{g}$ for peroxide value, and $39.12 \mathrm{mg} / \mathrm{g}$ to $106.16 \mathrm{mg} / \mathrm{g}$ for iodine value.

Table 2. Result of physicochemical properties of the oil bearing seed and nut

\begin{tabular}{l|l|l|l|l}
\hline Properties & Shea butter & Ground nut oil & Sesame oil & Neem oil \\
\hline Free fatty acid & $0.30 \pm 0.05$ & $0.63 \pm 0.03$ & $0.58 \pm 0.03$ & $2.87 \pm 0.78$ \\
\hline Peroxide value $(\mathrm{mg} / \mathrm{g})$ & $0.38 \pm 0.07$ & $1.71 \pm 0.14$ & $2.93 \pm 0.33$ & $1.41 \pm 0.21$ \\
\hline Iodine value $(\mathrm{g} / 100)$ & $39.12 \pm 2.32$ & $92.38 \pm 5.11$ & $106.16 \pm 5.5$ & $94.23 \pm 3.65$ \\
\hline Saponification value $(\mathrm{mgKOH} / \mathrm{g})$ & $195.22 \pm 4.15$ & $182.83 \pm 7.15$ & $188.23 \pm 4.33$ & $178.46 \pm 5.33$ \\
\hline Acid value $(\mathrm{mgKOH} / \mathrm{g})$ & $2.97 \pm 0.34$ & $2.13 \pm 0.27$ & $1.33 \pm 0.14$ & $17.98 \pm 0.54$ \\
\hline
\end{tabular}

From Table 2 shea butter oil has value of Free fatty acid (FFA), Peroxide value (PV), Iodine value (IV), Saponification value (SV), and Acid value (AV) of $0.3 \%, 0.38 \mathrm{mg} / \mathrm{g}, 39.12 \mathrm{mg} / \mathrm{g}, 195.22 \mathrm{mg} / \mathrm{g}$ and 2.97 respectively. Also ground nut oil has value of FFA, PV, IV, SV, and AV of $0.63 \%, 1.71 \mathrm{mg} / \mathrm{g}, 92.38$ $\mathrm{mg} / \mathrm{g}, 182.83 \mathrm{mg} / \mathrm{g}$ and 2.13 respectively. In addition sesame oil oil has value of FFA, PV, IV, SV, and AV of $0.58 \%, 2.93 \mathrm{mg} / \mathrm{g}, 106.16 \mathrm{mg} / \mathrm{g}, 188.23 \mathrm{mg} / \mathrm{g}$ and 1.33 respectively and respectively $2.87 \%, 1.41$ $\mathrm{mg} / \mathrm{g}, 94.23 \mathrm{mg} / \mathrm{g}, 178.46 \mathrm{mg} / \mathrm{g}$ and 17.98 for neem oil. [5] reported Iodine value of 116 (gI2/100g), oil content of $50 \%$, Acid value of $0.45(\mathrm{mq} \mathrm{KOH} / \mathrm{g})$, Peroxide value $7.45(\mathrm{mq} \mathrm{KOH} / \mathrm{g})$ and saponification value of 191 (mq KOH/g) for sesame oil. [15] reported free fatty acid of 1.015 to $4.5 \%$, Iodine value of 77.53 to 81.28 (gI2/100g), $\mathrm{KOH} / \mathrm{g}$ ) and saponification value of 180.54 to $190.84(\mathrm{mq} \mathrm{KOH} / \mathrm{g}$ ) for neem oil. Also [23], reported Iodine value of 36.6 to 41.3 (gI2/100g), oil content of 41 to $53.56 \%$, Acid value of 2.3 to 12.59 (mq KOH/g), Peroxide value 2.1 to $2.5(\mathrm{mq} \mathrm{KOH} / \mathrm{g})$ and saponification value of 160.35 to 192.15 (mq KOH/g) for shea nut oil. [1] reported Iodine value of $116(\mathrm{gI} 2 / 100 \mathrm{~g})$, oil content of 20 to $37.8 \%$, Free fatty acid value of 1.55 to 3.96 and saponification value of 188.1 to 220.2 (mq KOH/g) ground nut sesame oil.

The higher value of FFA in neem oil favours soap formation. This is similar to an earlier findings by [15] where high FFA values greater than standard value of $>2 \%(\mathrm{w} / \mathrm{w})$ found in neem oil was found to favour soap formation. The high saponification value obtained in this study indicated that all the oil can be used in soap and shampoo production. This is in line with result reported by [24] where saponification values contained in oil seed showed that it can be used in soap and shampoo production. High iodine values were observed in ground nut oil $(92.38 \mathrm{mg} / \mathrm{g})$, sesame oil $(106.16 \mathrm{mg} / \mathrm{g})$ and neem oil $(94.23 \mathrm{mg} / \mathrm{g})$ while lower value $(39.12 \mathrm{mg} / \mathrm{g})$ was observed in shea butter. This could be as result of polymerisation of glycerides content of the fatty acid in shea butter. This indicated that shea butter can best be used in soap making than the other oil under study. This result agreed with the findings of [15], where highly heating of unsaturated fatty acids results in polymerisation of glycerides which lead to the formation of deposits.

\section{Conclusions}

A steam heat generation system for pre-treatment of oil bearing seeds was successfully designed, fabricated and tested for efficient oil extraction. From the test results obtained for the performance evaluation of the fabricated machine, the following conclusions are made:The machine was able to effectively toast some oilseeds prior to oil extraction. The maximum oil yield of the sample were obtained at $8 \%, 6 \%, 6 \%$ and $10 \%$ for neem oil (42\%), ground nut oil (46\%), sesame oil (48\%) and shea nut $(2 \%)$ result of effects of moisture content on oil yield of the samples is presented in Figure 5. Sesame seed produced the highest oil yield of $48 \%$ at $6 \%$ moisture content (d.b) while ground nut produce lower oil yield of $20 \%$ at $12 \%$ moisture content (d.b). The values of oil yield range from $35 \%$ to $42 \%$ for neem oil, $20 \%$ to $46 \%$ for ground nut oil. Others are $25 \%$ to $48 \%$ and $35 \%$ to $40 \%$ for sesame oil and shea butter respectively. Increasing moisture content of the seed beyond $6 \%$ for sesame 
and ground nut seeds led to lower oil yield. Also increasing moisture content beyond $8 \%$ and $10 \%$ for neem and shea nut seeds respectively, led to lower oil yield. This implies that higher moisture content means lower oil yield. The entire oil samples extracted using the developed machine were fresh and clean. For the physicochemical analysis average values range from 0.3 to 2.87 for free fatty acid, 0.38 to 2.93 $\mathrm{mg} / \mathrm{g}$ for peroxide value, and $39.12 \mathrm{mg} / \mathrm{g}$ to $106.16 \mathrm{mg} / \mathrm{g}$ for iodine value. Neem oil has the highest FFA value of 2.87 while shea butter has the lower value of 0.30 . High saponification values were obtained from all the samples. High iodine values were observed in ground nut oil (92.38 mg/g), sesame oil (106.16 mg/g) and neem oil $(94.23 \mathrm{mg} / \mathrm{g})$ while lower value $(39.12 \mathrm{mg} / \mathrm{g})$ was observed in shea butter. The machine was found useful in eliminating the limitations and drudgery associated with direct roasting. Generally, the machine was found to be very adaptable for commercial toasting/roasting of oilseeds.

\section{References}

1. I. I. Nkafamiya, H. M. Maina, S. A. Osemeahon, and U. U. Modibbo, "Percentage oil yield and physiochemical properties of different groundnut species (Arachis hypogaea)", African Journal of Food Science, vol. 4, no. 7, pp. $418-421,2010$

2. M. G. Ibrahim, A. A. Shehu, S. M. Dauda, and D. Ahmad, D. "Design, fabrication and testing of shea nut shelling machine", International Food Research Journal 23(Suppl): S71 - S79, 2016

3. N. Aviara, F. Oluwole and M. Haque, "Effect of moisture content on some physical properties of shea nut (Butyrospernum paradoxum)," International Agrophysics, vol. 19, no,3, pp. 193-198, 2005

4. P. E. Ogbonna, and S. I. Ukaan, "Chemical composition and oil quality of seeds of sesame accessions grown in the Nsukka plains of South Eastern Nigeria", African Journal of Agricultural Research, vol. 8, no. 9, pp. 797-803, 2013.

5. M. I. Mohammed, and Z. U. Hamza, "Physicochemical Properties of Oil Extracts from Sesamum Indicum L. Seeds Grown in Jigawa State - Nigeria", Journal of Appl. Sci. Environ. Management, vol. 12, no. 2, pp. 99 - 101 , 2008.

6. A. Ibrahim, and A. P. Onwualu, "Technologies for Extraction of Oil from Oil-Bearing Agricultural Products: A Review", Journal of Agricultural Engineering and Technology (JAET), vol 3, pp. 58-70, 2005.

7. H. Zareiforoush, M. H. Komarizadeh and M. R. Alizadeh, "Effect of Moisture Content on Some Physical Properties of Paddy Grains", Research Journal of Applied Sciences, Engineering and Technology vol. 1, no. 3, pp. 132-139, 2009.

8. W. Yang, T. J. Siebenmorgen, T. P. H. Thielen, and A. G. Cnossen, "Effect of glass transition on conductivity of paddy", Biosyst. Eng, vol. 84, pp. 193-200.

9. R. S. Khurmi, and J. K. Gupta, "Machine Design", 14th Edition. S. Chand and Company Ltd., Ram Nagar, New Delhi, 2005, pp 434-960.

10.D. F. Othmer, and H. N. Huang, "Correlating Vapour pressure and latent heat data" In: Hand book of Cane Sugar Technology Oxford and IBH Publishing Co. Brisbane, Australia, 1985.

11.A. Gbabo, D. Ibrahim and I. M. Gana, "Design, fabrication and testing of an engine driven irrigation pump", Direct Research Journal of Engineering and Information Technology vol. 4, no. 1, pp 1-7, 2017.

12.J. Rayner, J., "Conduction through a Flat Plate or Wall in: Basic Engineering Thermodynamics", Longman Singapore Publishers (Pte) Ltd., Singapore, 1987.

13.B. A. Orhevba1, O. Chukwu, O. Z. Osunde, and V. Ogwuagwu, "Influence of moisture content on the yield of mechanically expressed neem seed kernel oil", Academic Research International, vol. 4, no. 5, 2013.

14.J. O. Olajide, "Process Optimisation and Modelling of Oil Expression from Groundnut and Sheanut Kernel", Ph.D Thesis, University of Ibadan, Nigeria, 2010.

15.P. Bhandare and G. R. Naik, "Functional properties of neem oil as potential feedstock for biodiesel production", International Letters of Natural Sciences vol. 7, pp.7-14, (2015).

16.P. Panneerselvam, N. Morad, A. K. Tan, "Magnetic nanoparticle (Fe3O4) impregnated onto tea waste for the removal of nickel (II) from aqueous solution", J. Hazard. Mat, vol. 186, pp. 160-168, 2011. 
17.R. Akinoso, "Effects of Moisture Content, Roasting Duration and Temperature on Oil Yield and Quality of Palm Kernel (Elaeis guineensis) and Sesame (Sesamium indicum) Oils. Ph.D Thesis, Department of Agricultural and Environmental Engineering, University of Ibadan, Ibadan, Nigeria, 2006

18.T. Y. Tunde-Akintunde, B. O. Akintunde, and J. C. Igbeka, "Effect of Processing Factors on Yield and Quality of Mechanically Expressed Soybeans Oil", Journal of Agricultural Engineering Technology, vol. 55, pp. 86-92, 2001.

19.O. K. Owolarafe, A. T. Adegunloye, and O. O. Ajibola, "Effects of Processing Condition on Oil Point Pressure of Locust Bean", Journal of Food Processing Engineering, vol. 26, no. 51, pp. 489-497, 2003.

20.B. S. Ogunsina, O. A. Koya, and O. O. Adeosun, "Deformation and Fracture of Dika Nut (Irvingia gabonensis) under Uni-axial Compressive Loading”, International Agrophysics, vol. 22, pp. 249-253.

21.J. Olaomi, "Design and Construction of a Motorised Groundnut Oil Expelling Machine', UnpublishedB.Eng Thesis, Department of Mechanical Engineering, University of Ilorin, Nigeria, 2008.

22.L. Gerald, "The Application of Fluid Mixers in Edible Oil Processing," 2009, http:www.emimixers.com.

23.J. B. L. Okullo, F. Omujal, J. G. Agea, P. C. Vuzi, A. Namutebi, J. B. A. Okello and S. A. Nyaazi, "Characterization of Shea butter Vitellaria paradoxa C.F. Gaertn) oil from the shea Districts of Uganda", African J. Food Agric. Nut. Develop, vol. 10, no. 1, pp. 2070-2084, 2010.

24.E. Z. Akbar, S. K. Yaakub, M. I. Kamarudin and J. Salimon, European Journal of scientific research, vol. 29, no. 3, pp. 396-403, 2009. 